\title{
Randomized Prospective Open Label Study Shows No Impact on Clinical Outcome of Adding Losartan to Hospitalized COVID-19 Patients with Mild Hypoxemia
}

\author{
Matthew Geriak • Fadi Haddad • Ravina Kullar • Kristina L. Greenwood • \\ MacKenzie Habib · Cole Habib · David Willms • George Sakoulas
}

Accepted: April 28, 2021 / Published online: May 11, 2021

(C) The Author(s) 2021

\section{ABSTRACT}

Introduction: Despite considerable scientific debate, there have been no prospective clinical studies on the effects of angiotensin II receptor blockers (ARBs) on the course of COVID-19 infection. Losartan is the ARB that was chosen to be tested in this study.

Methods: Patients with COVID-19 and mild hypoxia (receipt of $\leq 3 \mathrm{~L} / \mathrm{min} \mathrm{O}_{2}$ by nasal

M. Geriak ( $\square) \cdot$ D. Willms · G. Sakoulas

Sharp Memorial Hospital, Sharp Memorial Research Pharmacy, 7901 Frost Street, San Diego, CA 92123, USA

e-mail: matthew.geriak@sharp.com

F. Haddad

Sharp Grossmont Hospital, La Mesa, CA, USA

R. Kullar

Expert Stewardship, Inc, Santa Monica, CA, USA

M. Geriak · K. L. Greenwood · M. Habib · C. Habib

Sharp Center for Research, San Diego, CA, USA

D. Willms

Sharp Chula Vista Hospital, Chula Vista, CA, USA

G. Sakoulas

Sharp Rees-Stealy Medical Group, San Diego, CA, USA

G. Sakoulas

Collaborative To Halt Antibiotic-Resistant Microbes (CHARM), Department of Pediatrics, University of California San Diego School of Medicine, La Jolla, CA, USA cannula) admitted to three hospitals were randomized in a $1: 1$ ratio within $72 \mathrm{~h}$ of SARS-CoV2 nucleic acid testing confirmation to prospectively receive standard of care (SOC) alone or SOC plus losartan $12.5 \mathrm{mg}$ orally every $12 \mathrm{~h}$ for 10 days or until hospital discharge, with the option to titrate upward dependent on blood pressure tolerability. Primary composite endpoint was receipt of mechanical ventilation or death before receiving ventilation. Subjects were followed until discharge to home or until an endpoint was met in the hospital.

Results: Sixteen subjects received an ARB plus SOC and 15 subjects received SOC alone. The median age was 53 years for both groups. Median time from hospital admission to study enrollment was 2 days (range 1-6) for the ARB group and 2 days (range 1-4) for the SOC group. Mean Charlson comorbidity index was 2 for both groups. One subject in each group achieved the composite endpoint.

Conclusion: This small prospective randomized open-label study showed no clinically significant impacts of ARB therapy in mildly hypoxemic patients hospitalized with COVID-19 early in the pandemic. A larger prospective randomized placebo-controlled trial would be needed to confirm these findings or capture less pronounced effects and probably should focus on outpatients earlier in disease course.

Trial Registration: clinicaltrials.gov; March 27, 2020; NCT04340557. 
Keywords: ARB; COVID-19; Losartan; SARSCoV-2

\section{Key Summary Points}

\section{Why carry out this study?}

Repurposing of available drugs to treat patients during the rapidly spreading COVID-19 pandemic is of great interest.

Previous studies had hinted toward possible benefit of angiotensin receptor blockers in the treatment of SARS-CoV-2mediated respiratory disease.

This study evaluated whether the angiotensin receptor blocker therapy, losartan, could improve oxygenation and, therefore, shorten hospital stay and reduce mortality in patients with mild hypoxia due to COVID-19.

\section{What was learned from the study?}

Losartan did not significantly impact length of hospital stay or mortality when added to the standard of care in COVID19 infected patients with mild hypoxia.

A larger study will be needed of COVID-19 patients with less severe disease in the outpatient setting to better understand the role of angiotensin receptor blocker therapy in COVID-19.

\section{DIGITAL FEATURES}

This article is published with digital features, including a summary slide, to facilitate understanding of the article. To view digital features for this article go to https://doi.org/10.6084/ m9.figshare.14495577.

\section{INTRODUCTION}

COVID-19 infection, as is common with many types of viral and atypical infections, is characterized by a biphasic illness [1-3]. The first relatively mild protean phase is driven by viral replication and is the foundation of the majority of asymptomatic and symptomatic disease, resolving in about a week [1-3]. SARSCoV-2 spike protein binds to its receptor angiotensin converting enzyme II (ACE2) in order to enter the cell and begin viral replication [4]. Thus, this first phase of illness offers potential to use angiotensin receptor blocker II (ARB) to abort viral pathogenesis. The second phase, driven by the adaptive immune response to the viral infection, may lead to potentially catastrophic disease manifestations requiring hospitalization and intensive care in a minority of SARS-CoV-2-infected patients, characterized by acute respiratory distress syndrome (ARDS), vasculitis with thrombotic complications and systemic involvement [5-7]. Clinical studies are under way investigating immunomodulation of various forms to target this second phase of illness.

ARBs are currently being studied for early infected COVID-19 patients [8]. SARS-CoV and SARS-CoV-2 downregulate ACE2 by binding it via the viral spike (S1) protein, allowing for viral entry into the host cell [9]. After viral entry, the virus quickly replicates resulting in tissue injury. An ARB, like losartan, has the potential mechanism of action to inhibit viral cell entry by blocking the angiotensin II type 1 receptor (AT1R) [10]. This is the first study to prospectively evaluate the addition of an $A R B$ to otherwise standard treatment for adults with mild to moderate hypoxemia secondary to COVID-19.

\section{METHODS}

\section{Study Design}

This was an open-label randomized controlled trial performed at three hospital centers: Sharp Memorial Hospital (San Diego, CA, USA), Sharp Grossmont Hospital (La Mesa, CA, USA) and Sharp Chula Vista Hospital (Chula Vista, CA, USA). The research protocol was approved by the Sharp Healthcare Institutional Review Board (IRB \# 2003902) for all three sites prior to 
patient enrollment and was registered on clinicaltrials.gov (March 27, 2020; NCT04340557). All participants and/or legally authorized representatives were provided complete information about the risks and benefits of participation in this study. Subjects were made aware that results of the study would potentially be published free of any subject identifiers. All participants and/or legally authorized representatives signed an the informed consent form to participate in this study, which was documented via DocuSign ${ }^{\mathrm{TM}}$. This study was performed in accordance with the Declaration of Helsinki. The study design, process of local IRB approval and adherence to the requirements obtaining an informed consent are similar to our other published studies $[11,12]$.

\section{Study Population}

Adult patients $\geq 18$ years of age presenting with COVID-19 infection confirmed by positive polymerase chain reaction testing for the SARSCoV-2 genome in nasopharyngeal and/or nares swab sample were considered for inclusion if they demonstrated mild to moderate hypoxia $\left(\mathrm{SpO}_{2} \leq 96 \%\right.$ on $\geq 1 \mathrm{~L} / \mathrm{min} \mathrm{O}_{2}$ by nasal cannula) but not on mechanical ventilation.

\section{Treatments}

After informed consent was obtained, subjects were randomized 1:1 into the treatment arm (ARB) or standard of care (SOC) control arm. SOC consisted of the subject remaining on or being eligible for any treatment not part of a randomized clinical trial and considered standard of care at the time of enrollment. On May 13,2020 , and afterwards, this included the use of remdesivir. Patients were also eligible to receive convalescent plasma therapy as part of the nationally available compassionate use registry, which was informally accepted in our region as SOC. The ARB treatment arm consisted of the subject receiving an ARB (losartan-generic brand was locally sourced) 12.5 mg orally every $12 \mathrm{~h}$ for 10 days, beginning on the day of randomization, in addition to SOC. The treating physician had the option to titrate the dose upward if blood pressure allowed. Subjects were monitored for progression to the endpoint of (1) respiratory failure requiring receipt of mechanical ventilation (a composite of either receiving ventilation or the patient status changed to a do not resuscitate/do not intubate resulting in progressive respiratory failure and death) or (2) death from non-respiratory causes prior to receipt of mechanical ventilation. If the subject progressed to mechanical ventilation, receipt of off-label agents and/or enrollment in other clinical trials was allowed. The subject's hospital course was followed until hospital discharge.

\section{Clinical Data Extraction and Analysis}

Relevant clinical and laboratory information was captured to allow for group comparisons, including the calculation of the Charlson comorbidity index (https://www.mdcalc.com/ charlson-comorbidity-index-cci).

\section{Statistical Analysis}

Statistical differences in rates of receipt of mechanical ventilation and other categorical or ordinal variables were calculated using Fisher exact test, and differences in continuous variables were calculated using the Mann-Whitney $U$ test. $p<0.05$ was considered statistically significant.

\section{RESULTS}

\section{Baseline Patient Demographics and Clinical Characteristics}

Thirty-two patients were randomized with the intent to treat (ITT) between March 30 and July 4, 2020, 16 to receive ARB plus SOC and 15 to SOC alone. One patient in the ARB group did not receive losartan and was excluded from the analysis. Hypotension (SBP $<100)$ was similar in both groups (3/16 in ARB and 4/15 in SOC groups). Oxygen flow rate requirements were similar between the groups at enrollment (median ARB $0.5 \mathrm{~L} / \mathrm{min}$ vs. SOC $2.0 \mathrm{~L} / \mathrm{min}, p=0.41$, 
Mann-Whitney $U$ test) and at $48 \mathrm{~h}$ post-enrollment (median ARB and SOC $0 \mathrm{~L} / \mathrm{min}, p=0.37$, Mann-Whitney $U$ test). Total oxygen consumption (total liters) during the enrollment period was also similar between the two groups (median 5832 L ARB vs. 8208 L SOC, $p=0.31$ Mann-Whitney U test).

The remaining patient characteristics are listed in Table 1, demonstrating median age of 53 years in both groups, overall $61 \%$ males and a majority of Hispanic/Latino patients, consistent with the local demographics of COVID-19 in Southern California. Diabetes mellitus, hypertension and obesity were the most common comorbidities. The mean body mass index in the ARB and SOC groups were 31 and $29 \mathrm{~kg} /$ $\mathrm{m}^{2}$, respectively. Concomitant COVID-19 therapies received are also listed in Table 1 . Notably, because the vast majority of these patients were enrolled early in the pandemic (April and May 2020), only a minority of patients received glucocorticoid and remdesivir therapies. Thereafter, study enrollment dropped off considerably because of a rise in competing clinical trials.

\section{Clinical Outcomes, Safety and Tolerability}

Fifteen of 16 (94\%) ARB and 13/15 (87\%) SOC patients were discharged to home without need for ICU transfer or mortality. Two SOC patients (13.3\%) and 1 ARB patient (6.3\%) progressed to requiring ICU care. One patient in each group progressed to mechanical ventilation and died prior to discharge. Lengths of hospital stay were also similar between the groups ( 9 days for ARB, 10 days for SOC). No patient required ARB discontinuation because of tolerability or safety concerns.

\section{DISCUSSION}

Preclinical studies suggested the potential for either benefit or harm from renin-angiotensin system blockers in COVID-19 [13]. Initial concerns stemmed from the hypothesis that angiotensin-converting enzyme inhibitors (ACE-Is) and ARBs may upregulate angiotensin converting enzyme 2 (ACE2), which is used by
Table 1 Patient characteristics and outcomes

\begin{tabular}{|c|c|c|}
\hline & $\begin{array}{l}\text { ARB } \\
(n=16)\end{array}$ & $\begin{array}{l}\text { SOC } \\
(n=15)\end{array}$ \\
\hline Mean age (years) & 59 & 55 \\
\hline Median age (years) & 53 & 53 \\
\hline Male $N(\%)$ & $10(62.5)$ & $9((60)$ \\
\hline \multicolumn{3}{|l|}{ Race $N(\%)$} \\
\hline White & $1(6.3)$ & $2(13.3)$ \\
\hline Black/African American & $1(6.3)$ & $0(0)$ \\
\hline Hispanic & $2(75)$ & $13(86.7)$ \\
\hline Asian & $0(0)$ & $0(0)$ \\
\hline Unknown & $2(12.5)$ & $0(0)$ \\
\hline \multicolumn{3}{|l|}{ Median days } \\
\hline $\begin{array}{l}\text { Admission to enrollment } \\
\text { (range) }\end{array}$ & $2(1-6)$ & $2(1-4)$ \\
\hline $\begin{array}{l}\text { Mean Charlson Comorbidity } \\
\text { Index }\end{array}$ & 2 & 2 \\
\hline \multicolumn{3}{|l|}{ Comorbidities $N(\%)$} \\
\hline Diabetes mellitus & $3(18.8)$ & $5(33.3)$ \\
\hline Hypertension & $7(43.8)$ & $5(33.3)$ \\
\hline Obesity $\left(\right.$ BMI $\left.\geq 30 \mathrm{~kg} / \mathrm{m}^{2}\right)$ & $8(50)$ & $5(35.7)$ \\
\hline Mean BMI $\left(\mathrm{kg} / \mathrm{m}^{2}\right)$ & 31.1 & 28.8 \\
\hline Mean BMI of obese $\left(\mathrm{kg} / \mathrm{m}^{2}\right)$ & 35.8 & 35.0 \\
\hline Tobacco use & $4(25)$ & $2(13.3)$ \\
\hline Cardiovascular disease & $1(6.3)$ & $0(0)$ \\
\hline \multicolumn{3}{|c|}{ Concomitant SARS-CoV-2 medications $N(\%)$} \\
\hline Remdesivir & $4(25)$ & $5(33)$ \\
\hline Glucocorticoids $>2$ doses & $2(12.5)$ & $5(33)$ \\
\hline Azithromycin & $2(12.5)$ & $3(20)$ \\
\hline Hydroxychloroquine & $2(12.5)$ & $1(6.7)$ \\
\hline Convalescent plasma & $1(6.3)$ & $1(7)$ \\
\hline Anti-thrombotics & $16(100)$ & $15(100)$ \\
\hline \multicolumn{3}{|l|}{ Outcomes $N(\%)$} \\
\hline $\begin{array}{l}\text { Discharge without } \\
\text { progression to ICU }\end{array}$ & $15(93.8)$ & $13(86.7)$ \\
\hline ICU transfer & $1(6.3)$ & $2(13.3)$ \\
\hline
\end{tabular}


Table 1 continued

\begin{tabular}{|c|c|c|}
\hline & $\begin{array}{l}\text { ARB } \\
(n=16)\end{array}$ & $\begin{array}{l}\text { SOC } \\
(n=15)\end{array}$ \\
\hline In-hospital mortality & $1(6.3)$ & $1(6.7)$ \\
\hline Mean length of stay (days) & 9 & 10 \\
\hline
\end{tabular}

SARS-CoV-2 as an entry portal into pneumocytes and other cells, thereby facilitating viral infection and increasing illness severity. Mechanisms have been proposed by which ARB may upregulate ACE2 and decrease viral entry by formation of complexes between angiotensin II type 1 receptors and membrane-bound ACE2. This would offer potential therapeutic benefit, particularly in early COVID-19. Retrospective observational studies are marked by bias and other methodologic concerns so the overall neutral findings are of limited value [14-21]. Two recent meta-analyses have shown no benefit or harm of ARBs in COVID-19 [22, 23]. Interestingly, however, ACE-I and ARBs have been documented to be lung protective, suggesting possible benefit in renin angiotensin system blockade in pneumonia [24].

This study enrolled 32 ITT COVID-19 subjects who were randomized to receive losartan $\mathrm{ARB}$ in addition to SOC at the time versus SOC alone. We noted no significant differences in progression from mild hypoxia to severe disease requiring ICU transfer, mechanical ventilation or in-hospital mortality with addition of ARB. This is consistent with the overall neutral findings of retrospective observational studies and fully supports the recommendations early in the COVID-19 pandemic by the American Heart Association, American College of Cardiology, Heart Failure Society of America, Canadian Heart Failure Society, Canadian Heart Failure Society and European Society of Cardiology to not discontinue or alter therapy on patients already on ACE-I or ARB to mitigate the risk of COVID-19 infection or to affect COVID-19 treatment outcome.

Although limited by its small size, unblinded design and being restricted to three hospitals in close proximity in one geographic area, this study suggests that ARB therapy may not influence COVID-19 pathogenesis. This may be less surprising now than it was at the beginning of the COVID-19 pandemic given what we have learned about the pathophysiology of severe COVID-19 infection, namely that progressive more severe disease is driven by system immunologic and coagulopathic mechanisms in the setting of a waning viral presence $[2,3,5,6]$. Furthermore, given the evolution of SOC therapy over the past year, with the introduction of remdesivir in mid-May 2020 [25-27] and the mainstream adoption of glucocorticoid therapy in mid-June 2020 [28], it is likely that potentially small signals of ARB clinical benefit that might have been captured in a more treatment-naïve background will be much more difficult to capture in the setting of current treatment paradigms. Other up and coming COVID-19 therapies such as SARS-CoV2 monoclonal antibodies [29] and the use of intravenous immunoglobulins [11] will likely further hamper the study of ARB in the future. Indeed, the limited clinical utility of direct antiviral therapies is coming to light in larger scale assessments [30].

\section{CONCLUSIONS}

This small prospective study of ARB (losartan) therapy L mildly hypoxic COVID-19 patients early in the pandemic, largely before the adoption of remdesivir and glucocorticoid therapies, showed no clinical benefit or harm in hospitalized patients with COVID-19. While larger randomized studies are needed to provide more definitive validation of these findings, we believe that it is unlikely that the evolving COVID-19 treatment paradigms will allow for any small signals of potential benefit or harm of ARB to be captured among hospitalized COVID19 patients. Future studies of ARB therapy likely should focus on outpatients very early in their COVID-19 illness. 


\section{ACKNOWLEDGEMENTS}

We thank all the study participants and their legal authorized representatives (if applicable) for participating in this study early on in the COVID-19 pandemic in the US.

Funding. This research was supported Sharp Healthcare Foundation (San Diego, CA, USA). The funding was only for the labor of the local IRB review and the labor for the Sharp Center of Research support staff. There was no funding assistance for publication. The journal's Rapid Service Fee was funded by the authors.

Authorship. All named authors meet the International Committee of Medical Journal Editors (ICMJE) criteria for authorship for this manuscript, take responsibility for the integrity of the work as a whole and have given their approval for this version to be published. All authors were active participants in at least one category of study design, study execution, data gathering and organization, data analysis and statistics, or manuscript preparation.

Authors' Contributions. Matthew Geriak: Study design, execution, data gathering and organization, data analysis, manuscript preparation. Fadi Haddad: Data analysis, subject referrals. Ravina Kullar: Data analysis and statistics. Kristina L. Greenwood: Data gathering and organization, data analysis. MacKenzie Habib: Data gathering and organization. Cole Habib: Data gathering and organization. David Willms: Data analysis,. George Sakoulas: Study design, subject referrals, data analysis, manuscript preparation, study team oversight.

Disclosures. Matthew Geriak: has nothing to disclose. Fadi Haddad: has nothing to disclose. Ravina Kullar: has nothing to disclose. Kristina L. Greenwood: has nothing to disclose. MacKenzie Habib: has nothing to disclose. Cole Habib: has nothing to disclose. David Willms: has received speaking honoraria from La Jolla Pharmaceutical Company. George Sakoulas: has received speaking honoraria from Allergan, Sunovion and consulting fees from Allergan and Paratek Pharmaceuticals.
Compliance with Ethics Guidelines. The research protocol was approved by the Sharp Healthcare Institutional Review Board (IRB \# 2003902) for all three sites prior to patient enrollment. The study was performed in accordance with the Declaration of Helsinki. All participants and/or legally authorized representatives were provided complete information about the risks and benefits of participation prior to informed consent being obtained. All participants and/or legally authorized representatives signed to participate in this study on the informed consent form, and the signing to participate in this study was documented via DocuSign $^{\mathrm{TM}}$. Subjects were made aware that results of the study would potentially be published free of any subject identifiers. We are extremely grateful to our study participants for allowing us to participate in their care, especially during the most challenging of times of great uncertainty during the COVID-19 pandemic.

Data Availability. Datasets generated during and/or analyzed during the current study are available in collaboration upon communication with the corresponding author and approval of Sharp IRB.

Open Access. This article is licensed under a Creative Commons Attribution-NonCommercial 4.0 International License, which permits any non-commercial use, sharing, adaptation, distribution and reproduction in any medium or format, as long as you give appropriate credit to the original author(s) and the source, provide a link to the Creative Commons licence, and indicate if changes were made. The images or other third party material in this article are included in the article's Creative Commons licence, unless indicated otherwise in a credit line to the material. If material is not included in the article's Creative Commons licence and your intended use is not permitted by statutory regulation or exceeds the permitted use, you will need to obtain permission directly from the copyright holder. To view a copy of this licence, visit http://creativecommons.org/licenses/by$\mathrm{nc} / 4.0 /$. 


\section{REFERENCES}

1. Chen N, Zhou M, Dong X, et al. Epidemiological and clinical characteristics of 99 cases of 2019 novel coronavirus pneumonia in Wuhan, China: a descriptive study. Lancet. 2020;395:5017-513. https://doi.org/10.1016/S0140-6736(20)30211-7.

2. Siddiqu HK, Mehra MR. COVID-19 illness in native and immunosuppressed states: a clinical-therapeutic staging proposal. J Heart Lung Transplant. 2020. https://doi.org/10.1016/j.healun.2020.03.012.

3. Qin C, Zhou L, Hu Z, et al. Dysregulation of immune response in patients with COVID-19 in Wuhan, China. Clin Infect Dis. 2020. https://doi. org/10.1093/cid/ciaa248.

4. Shang J, Wan Y, et al. Cell entry mechanisms of SARS-CoV-2. PNAS. 2020;117:11727-34. https:// doi.org/10.1073/pnas.2003138117.

5. Nicolai L, Leunig A, Brambs S, Kaiser R, Weinberger T, Weigand M, Muenchhoff M, Hellmuth JC, Ledderose S, Schulz H, Scherer C, Rudelius M, Zoller M, Hochter D, Keppler O, Teupser D, Zwibler B, von Bergwelt-Baildon M, Kaab S, Massberg S, Pekayyvaz $\mathrm{K}$, Stark K. Immunothrombotic dysregulation in COVID-19 pneumonia is associated with respiratory failure and coagulopathy. Circulation. 2020;142:1176-89 (e-pub).

6. Cicco S, Cicco G, Racanelli V, Vacca A. Neutrophil extracellular traps (NETs) and damage-associated molecular patterns (DAMPs): two potential targets for COVID-19 treatment. Mediat Inflamm. 2020;2020:7527953. https://doi.org/10.1155/2020/ 7527953.

7. Uozumi R, Iguchi R, Masuda S, Nishibata Y, Nakazawa D, Tomaru U, Ishizu A. Pharmaceutical immunoglobulins reduce neutrophil extracellular trap formation and ameliorate the development of MPO-ANCA-associated vasculitis. Mod Rheumatol. 2020;30(3):544-50. https://doi.org/10.1080/ 14397595.2019 .1602292 .

8. https://www.clinicaltrials.gov/ct2/results?cond= Coronavirus\&term $=$ losartan $\&$ cntry $=\&$ state $=\&$ city $=$ \&dist $=$.

9. Ciulla MM. SARS-CoV-2 downregulation of ACE2 and pleiotropic effects of ACEIs/ARBs. Hypertens Res. 2020;43:985-6. https://doi.org/10.1038/ s41440-020-0488-z.

10. Gurwitz D. Angiotensin receptor blockers as tentative SARS-CoV-2 therapeutics. Drug Dev Res. 2020;81(5):537-40. https://doi.org/10.1002/ddr. 21656 (Epub 2020 Mar 4).
11. Sakoulas G, Geriak M, Kullar R, Greenwood KL, Habib M, Vyas A, Ghafourian M, Dintyala VNK, Haddad F. Intravenous immunoglobulin plus methylprednisolone mitigate respiratory morbidity in coronavirus disease 2019. Crit Care Explor. 2020;2(11):e0280. https://doi.org/10.1097/CCE. 0000000000000280.PMID:33225306;PMCID: PMC7671875.

12. Geriak M, Haddad F, Rizvi K, Rose W, LaPlante K, Yu M, Vasina L, Ouellette K, Zervos M, Nizet V, Sakoulas G. Clinical data on daptomycin plus ceftaroline versus standard of care monotherapy in the treatment of methicillin-resistant Staphylococcus aureus bacteremia. Antimicrob Agents Chemother. 2019;63(5):e02483-e2518. https://doi.org/10.1128/ AAC.02483-18.

13. Mackey K, King VJ, Gurley S, Kiefer M, Liederbauer E, Vela K, Sonnen P, Kansagara D. Risks and impact of angiotensin-converting enzyme inhibitors or angiotensin-receptor blockers on SARS-CoV-2 infection in adults: a living systematic review. Ann Intern Med. 2020;173(3):195-203. https://doi.org/ 10.7326/M20-1515 (Epub 2020 May 15).

14. Reynolds HR, et al. Renin-angiotensin-aldosterone system inhibitors and risk of Covid-19. N Engl J Med. 2020. https://doi.org/10.1056/NEJMoa200 8975 (e-pub).

15. Mancia G, et al. Renin-angiotensin-aldosterone system blockers and the risk of Covid-19. N Engl J Med. 2020. https://doi.org/10.1056/NEJMoa200 6923 (e-pub).

16. de Abajo FJ, et al. Use of renin-angiotensin-aldosterone system inhibitors and risk of COVID-19 requiring admission to hospital: a case-population study. Lancet. 2020. https://doi.org/10.1016/S01406736(20)31030-8 (e-pub).

17. Li J, et al. Association of renin-angiotensin system inhibitors with severity or risk of death in patients with hypertension hospitalized for coronavirus disease 2019 (COVID-19) infection in Wuhan, China. JAMA Cardiol. 2020. https://doi.org/10. 1001/jamacardio.2020.1624 (e-pub).

18. Zhang $\mathrm{P}$, et al. Association of inpatient use of angiotensin converting enzyme inhibitors and angiotensin II receptor blockers with mortality among patients with hypertension hospitalized with COVID-19. Circ Res. 2020. https://doi.org/10. 1161/CIRCRESAHA.120.317134 (e-pub).

19. Bean DM, et al. Treatment with ACE-inhibitors is associated with less severe disease with SARS-Covid19 infection in a multi-site UK acute hospital trust. MedRxiv. 2020. https://doi.org/10.1101/2020.04. 07.20056788 (Preprint). 
20. Turgeon RD, Zieroth S, Bewick D, Chow CM, Clarke B, Cowan S, Fordyce CB, Fournier A, Gin K, Gupta A, Hardiman S, Jackson S, Lau B, Leong-Poi H, Mansour S, Marelli A, Quraishi AR, Roifman I, Ruel M, Sapp J, Singh G, Small G, Virani S, Wood DA, Krahn A. Use of renin-angiotensin system blockers during the COVID-19 pandemic: early guidance and evolving evidence. Can J Cardiol. 2020;36(8): 1180-2. https://doi.org/10.1016/j.cjca.2020.05.033 (Epub 2020 Jun 2).

21. Messerli FH, Siontis GCM, Rexhaj E. COVID-19 and renin angiotensin blockers: current evidence and recommendations. Circulation. 2020;141(25): 2042-4. https://doi.org/10.1161/CIRCULATIONA HA.120.047022 (Epub 2020 Apr 13).

22. Zhang G, Wu Y, Xu R, Du X. Effects of renin-angiotensin-aldosterone system (RAAS) inhibitors on disease severity and mortality in patients with COVID-19: a meta-analysis. J Med Virol. 2020. https://doi.org/10.1002/jmv.26695 (Epub ahead of print).

23. Cai XJ, Tay JCK, Kui SL, Tin AS, Tan VH. Impact of angiotensin-converting enzyme inhibitors and angiotensin receptor blockers on in-hospital mortality in COVID-19 patients: a systematic review and meta-analysis. Singap Med J. 2020. https://doi. org/10.11622/smedj.2020159 (Epub ahead of print).

24. Caldeira D, Alarcão J, Vaz-Carneiro A, Costa J. Risk of pneumonia associated with use of angiotensin converting enzyme inhibitors and angiotensin receptor blockers: systematic review and metaanalysis. BMJ. 2012;345:e4260. https://doi.org/10. 1136/bmj.e4260.

25. Beigel JH, Tomashek KM, Dodd LE, et al. Remdesivir for the treatment of Covid-19-preliminary report [published online ahead of print, 2020 May 22]. N Engl J Med. 2020. https://doi.org/10.1056/ NEJMoa2007764.

26. Wang Y, Zhang D, Du G, et al. Remdesivir in adults with severe COVID-19: a randomised, double-blind, placebo-controlled, multicentre trial [published correction appears in Lancet. 2020 May 30;395(10238):1694]. Lancet. 2020;395(10236): 1569-78. https://doi.org/10.1016/S0140-6736(20) 31022-9.

27. Goldman JD, Lye DCB, Hui DS, et al. Remdesivir for 5 or 10 days in patients with severe Covid-19 [published online ahead of print, 2020 May 27]. N Engl J Med. 2020. https://doi.org/10.1056/ NEJMoa2015301.

28. RECOVERY Collaborative Group, Horby P, Lim WS, et al. Dexamethasone in hospitalized patients with Covid-19-preliminary report [published online ahead of print, 2020 Jul 17]. N Engl J Med. 2020. https://doi.org/10.1056/NEJMoa2021436.

29. Mahase E. Covid-19: FDA authorises neutralising antibody bamlanivimab for non-admitted patients. BMJ. 2020;11(371):m4362. https://doi.org/10.1136/ bmj.m4362.

30. WHO Solidarity Trial Consortium, Pan H, Peto R, Henao-Restrepo AM, Preziosi MP, Sathiyamoorthy V, Abdool Karim Q, Alejandria MM, Hernández García C, Kieny MP, Malekzadeh R, Murthy S, Reddy KS, Roses Periago M, Abi Hanna P, Ader F, AlBader AM, Alhasawi A, Allum E, Alotaibi A, AlvarezMoreno CA, Appadoo S, Asiri A, Aukrust P, BarrattDue A, Bellani S, Branca M, Cappel-Porter HBC, Cerrato N, Chow TS, Como N, Eustace J, García PJ, Godbole S, Gotuzzo E, Griskevicius L, Hamra R, Hassan M, Hassany M, Hutton D, Irmansyah I, Jancoriene L, Kirwan J, Kumar S, Lennon P, Lopardo G, Lydon P, Magrini N, Maguire T, Manevska S, Manuel O, McGinty S, Medina MT, Mesa Rubio ML, Miranda-Montoya MC, Nel J, Nunes EP, Perola M, Portolés A, Rasmin MR, Raza A, Rees H, Reges PPS, Rogers CA, Salami K, Salvadori MI, Sinani N, Sterne JAC, Stevanovikj M, Tacconelli E, Tikkinen KAO, Trelle S, Zaid H, Røttingen JA, Swaminathan S. Repurposed antiviral drugs for Covid-19-interim WHO solidarity trial results. N Engl J Med. 2020. https://doi.org/10.1056/NEJMoa2023184 (Epub ahead of print). 